\title{
Cell growth and calcification result from uncoupled physiological processes in the soft coral Litophyton arboreum
}

\author{
Ernestina Tentori ${ }^{1,3, *}$, Denis Allemand ${ }^{2}$, Ross Shepherd $^{1}$ \\ ${ }^{1}$ Central Queensland University, Bruce Highway, Rockhampton, Queensland 4702, Australia \\ ${ }^{2}$ Centre Scientifique de Monaco, Av Saint Martin MC 98000, Principaute de Monaco \\ ${ }^{3}$ Present address: School of Biological Sciences, Sydney University, New South Wales 2006, Australia
}

\begin{abstract}
Cellular growth and calcification were measured in branch tips of the soft coral Litophyton arboreum (Cnidaria, Octocorallia, Alcyonacea). We measured cell growth rates as ${ }^{3} \mathrm{H}$ thymidine incorporated into tissues, and calcification as ${ }^{45} \mathrm{Ca}$ incorporated into sclerites, during $2 \mathrm{~h}$ incubations in labelled seawater. Both parameters were normalised against soft coral protein content and analysed separately as stem and polyp responses. The experiments were run at various points during coral recovery from dissection. Stems and polyps showed their lowest cell growth rate immediately after injury due to cutting (Days 1 to 3 ), and their highest cell growth rate during recovery time (Days 7 to 49). In all experiments, the cell growth rate of stems was significantly higher than that of polyps. By contrast, no significant difference was detected between calcification rates of stems and polyps of the fully recovered microcolonies (Days 7 to 81). This study documents for first time the independent progress of cell growth and calcification mechanisms in tropical corals. It also demonstrates the contrasting physiological potential between the body regions of soft coral colonies.
\end{abstract}

KEY WORDS: Cell growth $\cdot$ Calcification $\cdot$ Functional polarity $\cdot$ Soft corals

\section{INTRODUCTION}

One of the most striking features of Indo Pacific coral reefs is the presence and diversity of soft corals (Cnidaria: Alcyonacea). Soft corals are important space competitors, assisted by the production of metabolites that can arrest their neighbours' growth by causing cell necrosis on contact, by triggering zooxanthellae expulsion, or by preventing larval settlement (see review by Coll 1992). Apart from affecting their neighbours, soft corals must grow fast to occupy the space made available by interspecific competition. Soft coral growth is a key factor in the extent to which they dominate vast areas of coral reef (Tursch \& Tursch 1982, Reichelt et al. 1986, Benayahu et al. 1990, Maida et al. 2001, Ninio \& Meekan 2002), particularly as a result of disturbance (Alino et al. 1992, Done 1992, Tentori 1999). The role of soft corals in coral reefs and the envi- ronmental factors that regulate their growth are not yet understood.

The terms growth and calcification tend to be used interchangeably in studies of scleractinian corals to indicate gain of coral mass, surface area and weight, and linear extension (Barnes \& Crossland 1980, Muscatine et al. 1985, Davies 1989, Vago et al. 1997). However, while biomass gain represents cellular growth, calcium carbonate gain represents calcification. Although both processes cause colony growth, these 2 functions may respond to different needs and have different metabolic requirements. If separate control mechanisms exist in scleractinian corals, they remain unnoticed, partly because of the way the thin live tissue mirrors the skeleton accretion surfaces (Johnston 1980, Isa \& Yamazato 1981, Gladfelter 1983, Marshall \& Wright 1993), superimposing the physiological processes involved. Soft corals form calcareous skeletons 
like other cnidarians such as stony corals and gorgonians, but their colony structure differs significantly. Compared to stony corals and gorgonians, soft corals possess a high proportion of cellular material and a low proportion of calcareous skeletal mass (generally in the form of free microscopic sclerites), as a result of which they appear soft. The calcifying cells and sclerites can be found throughout the bulk of the colony while the zooxanthellae, when present, are concentrated in the gastrodermis of their superficial polyps (i.e. cortical polyps) (E. Tentori pers. obs.). The contrasting morphology between soft corals and other calcifying corals could be fundamental in differentiating unresolved cnidarian physiology issues, such as the apparent overlapping progression of cell growth and calcification, and the long-debated model of lightenhanced calcification (Rinkevich \& Loya 1984, Marshall 1996, Gattuso et al. 1999).

In preliminary experimental runs, we tried to measure calcification rates as a general indication of coral growth, following the ${ }^{45} \mathrm{Ca}$-labelling methodologies used in scleractinian corals (Goreau 1959). The experiments showed a wide range of variation with no clear pattern of ${ }^{45} \mathrm{Ca}$ uptake in the microcolony sections. These unexpected responses suggested a problem due to the different times of recovery from dissection and led us to investigate growth by an alternative method, measuring cellular as well as skeletal formation. We call these processes cell growth and calcification respectively.

Using Litophyton arboreum as a model in this study, we address the following questions: (1) Do all parts of the colony grow/calcify at similar rates? (2) Is cell growth coupled to calcification? (3) How does experimental fragmentation of a colony affect cell and skeletal growth?

\section{MATERIALS AND METHODS}

Experimental organism. Litophyton arboreum (Forskål, 1775) (family: Nephtheidae) grows in IndoPacific reefs (Williams 1992) as arborescent colonies that can reach $1 \mathrm{~m}$ height (Berner et al. 1987). The polyp (anthocodia) region is clearly defined in these corals. Around 20 polyps emerge in groups from stems that branch vertically from one hollow, thick-walled base. The colonies are gonochoric and, in natural conditions in the Red Sea, their breeding season occurs between July and August (Benayahu et al. 1992). The development of oocytes takes 18 to 24 mo. Therefore, in the field, gonads can be found all year round. L. arboreum is found from the surface to $18 \mathrm{~m}$ depth, but its highest densities are at depths of 1 to $10 \mathrm{~m}$ (Benayahu et al. 1990). L. arboreum is a zooxanthellate cnidarian, and its branches can range from dark greenpurple to pale green-yellow in response to low and high light intensity, respectively. The taxonomic status of this species is uncertain (L. P. van Ofwegen pers. comm.). A sample of the experimental parent colonies has been deposited at the National Museum of Natural History, Leiden, The Netherlands, to be re-assessed once the taxonomic review is completed.

Preparation of microcolonies. The soft corals used in these experiments were obtained in the Gulf of Aqaba, Red Sea, and have been kept for a number of years in aquarium conditions at the Museum of Oceanography, Monaco. As experimental units we used microcolonies similar to those used in studies of stony corals (Al-Moghrabi et al. 1993, 1995, Tambutté et al. 1995a, 1996, Goiran et al. 1996, Romaine et al. 1997, Furla et al. 2000). This kind of preparation allows the use of multiple colonies with similar physiological and genetic characteristics. Since the microcolonies grow in laboratory-controlled conditions, environmental variables are eliminated, resulting in the expression of similar phenotypes. Furthermore, the use of such clones makes the repetition of experiments easier and facilitates the use of micromethods. For the present study, the tips of branches of 4 parent colonies were cut to obtain 12 to $15 \mathrm{~mm}$ long microcolonies with distinctive regions of stem and polyps (Fig. 1).

The microcolonies were maintained in a 3001 experimental aquarium (12 h light:12 h dark photoperiod; $200 \mu \mathrm{mol}$ photons $\mathrm{m}^{-2} \mathrm{~s}^{-1}$ light intensity; $26 \pm 0.1^{\circ} \mathrm{C}_{\text {; }}$ $38.2 \%$ salinity; open circulation system allowing the exchange of $2 \%$ of seawater volume $\mathrm{h}^{-1}$ ). To avoid fast

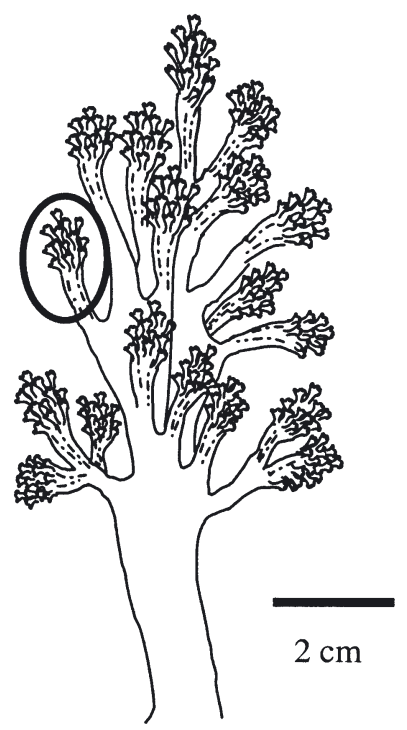

Fig. 1. Litophyton arboreum. The drawing represents a parent colony. Microcolonies consisting of 1 stem and associated polyps were prepared by cutting sections such as the encircled branch. See text for further details 
attachment to the substrate, the microcolonies were held in nylon mesh baskets inside the aquarium.

Microcolonies of Litophyton arboreum were used at 1 to $82 \mathrm{~d}$ of recovery from dissection. The parent colonies had branches with polyps of various shades of mauve-brown; no distinction was made amongst the resulting microcolonies for the purpose of this study. No gonads were observed in the experimental colonies. L. arboreum microcolonies generally attached to the substrate within $3 \mathrm{~d}$ after the time of dissection. As soon as they were attached, minute algae filaments settled on and around their base. To avoid the presence of live cells, other than $L$. arboreum and its endosymbionts, the microcolonies were cleaned daily by gentle weeding with fine forceps. An hour before running an experiment, the microcolonies were cleaned of algae and checked for any attached particles, under a dissecting microscope. The parent colonies and the microcolonies had no regular pattern of expansion and contraction times in the aquarium, but the microcolonies always opened to maximum expansion while incubated. The wet weight of some microcolonies was obtained by adding a microcolony to a known weight of filtered seawater (FSW) just before incubation.

Cell growth measurements. Cell growth was determined by incorporation of tritiated thymidine into the coral tissues. Methyl- ${ }^{3} \mathrm{H}$-thymidine $\left({ }^{3} \mathrm{H}-\mathrm{T}\right)$ was supplied by Dupont New England Nuclear (NEN). Each microcolony was incubated for $2 \mathrm{~h}$ in $9 \mathrm{ml} \mathrm{FSW} \mathrm{(filtered}$ through a $0.45 \mu \mathrm{m}$ Millipore filter) plus ${ }^{3} \mathrm{H}-\mathrm{T}$ to give a volumic activity $\sim 0.83 \mathrm{kBq} 100 \mathrm{\mu l}^{-1}$. All incubations were initiated between 09:00 and 10:00 h. The same conditions of light, temperature and salinity of the experimental aquarium were maintained during the incubations. The microcolonies fitted easily within a nylon mesh basket in the incubation vessel. The use of this basket reduced the problem of disturbance by manipulation and the resulting quick contractions of the colonies. Some fragments fitted more loosely than others in the holding basket, therefore their orientation throughout incubation was variable.

The medium was stirred by a magnetic bar placed under the nylon basket. After incubation, the coral was dissected into stem and polyp fragments. Each fragment was homogenised and sonicated in $1 \mathrm{ml}$ distilled water. ${ }^{3} \mathrm{H}$-T-labelled macromolecules were separated from free ${ }^{3} \mathrm{H}-\mathrm{T}$ by 2 consecutive steps of precipitation with $2 \mathrm{ml} 20 \%$ trichloroacetic acid (TCA) and kept at $0^{\circ} \mathrm{C}$ for $15 \mathrm{~min}$. After each precipitation, the solution was centrifuged at $1400 \times g$ and $20^{\circ} \mathrm{C}$ for $5 \mathrm{~min}$. The supernatant containing free ${ }^{3} \mathrm{H}-\mathrm{T}$ was discarded. The pellet obtained, corresponding to coral macromolecules, was washed twice with distilled water and centrifuged at $1400 \times g$ and $20^{\circ} \mathrm{C}$ for $5 \mathrm{~min}$.
The resulting pellet was resuspended in $400 \mu \mathrm{l}$ of $1 \mathrm{~N}$ $\mathrm{NaOH}$, sonicated and vortexed with $2 \mathrm{ml}$ distilled water. The final solution was sampled for ${ }^{3} \mathrm{H}-\mathrm{T}$ and protein analysis. Cell growth rates were recorded as dpm $\mathrm{mg}^{-1}$ protein $\mathrm{h}^{-1}$.

Calcification measurements. Calcification was measured by incorporation of ${ }^{45} \mathrm{Ca}$ into the sclerites of Litophyton arboreum microcolonies. ${ }^{45} \mathrm{CaCl}_{2}$ was supplied by NEN. The incubation medium was prepared by mixing $9 \mathrm{ml} \mathrm{FSW}$ and ${ }^{45} \mathrm{CaCl}_{2}\left(1 \mu \mathrm{Ci} \mathrm{ml}^{-1}\right)$. The microcolonies were incubated individually for $2 \mathrm{~h}$. All incubations were initiated between 09:00 and 10:00 h. At the end of incubation the microcolonies were rinsed in $100 \mathrm{ml} F S W$ for $10 \mathrm{~s}$ and immediately placed in $20 \mathrm{ml}$ of FSW to allow efflux of ${ }^{45} \mathrm{Ca}$ contained in the gastric cavities to be monitored, i.e. that not associated with calcification. Efflux was allowed for $3 \mathrm{~h}$; within this time equilibrium of internal and external medium was achieved for most colonies.

The microcolonies were taken out of the efflux medium and dissected into polyps and stem fragments. Each fragment was homogenised and sonicated in $5 \mathrm{ml}$ of $100 \%$ acetone, measurements of chlorophyll extracted at 24 and $48 \mathrm{~h}$ were performed as in Gattuso et al. (1993). The remaining pellet was mixed with $5 \mathrm{ml}$ $1 \mathrm{~N} \mathrm{NaOH}$, heated to $90^{\circ} \mathrm{C}$ for $30 \mathrm{~min}$, cooled to room temperature and centrifuged at $1400 \times g$ for $20 \mathrm{~min}$. The supernatant, which contained the tissue fraction, was analysed for protein content. The pellet, containing the sclerites, was oven-dried overnight $\left(60^{\circ} \mathrm{C}\right)$, weighed and finally digested in $1 \mathrm{ml} 1 \mathrm{~N} \mathrm{HCl}$. Distilled water $(1 \mathrm{ml})$ was added to avoid quenching when measuring ${ }^{45} \mathrm{Ca}$ activity. Calcification rates were recorded as nmole Ca $\mathrm{mg}^{-1}$ protein $\mathrm{h}^{-1}$.

In both experiments, $100 \mu \mathrm{l}$ aliquots of the labelled solutions were mixed in $4 \mathrm{ml}$ of Lumax scintillation cocktail. Radioactivity was measured in a Packard scintillation counter (Tricarb $1600 \mathrm{CA}$ ) in ${ }^{3} \mathrm{H}$ - and ${ }^{45} \mathrm{Ca}$ specific channels. Protein analysis was performed according to the method of Bradford (1976) using Coomasie $^{\mathrm{R}}$ Protein Assay Reagent and albumin standard.

Experimental design. Growth rates were measured at weekly intervals for $49 \mathrm{~d}$ following dissection from the parent colony. All growth experiments were run with 6 microcolony replicates incubated individually. Calcification rates were measured at Days $7,15,51$ and 82 after recovery from sectioning, with 6 replicates incubated individually. One-way ANOVA was used to test the effect of recovery time on growth and calcification rates, separately for each body region. Growth and calcification rates were log transformed before analysis to stabilise the variance. The least significant difference (LSD) test was used at the 5\% level to compare the mean log growth and calcifica- 

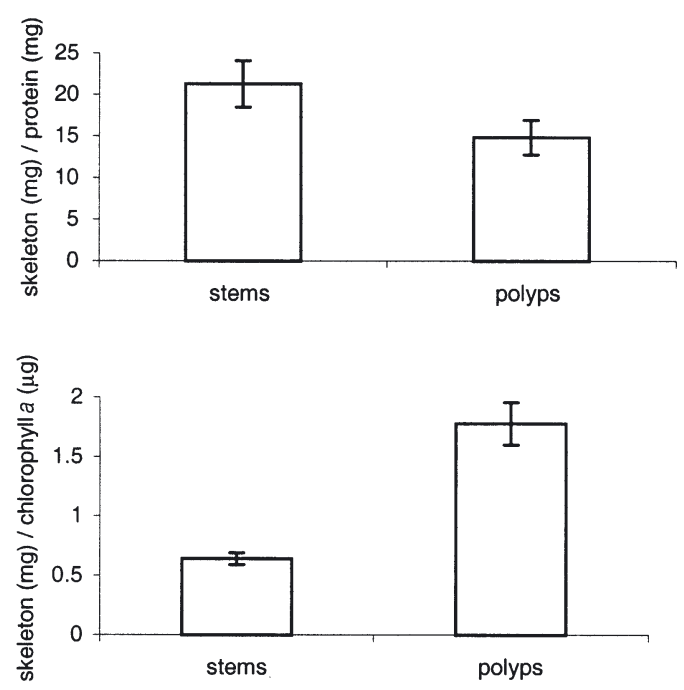

Fig. 2. Litophyton arboreum. Skeletal mass, chloroplasts and protein are not homogeneously distributed in the microcolony. (a) Skeletal (mg)/protein (mg) mass ratios, $\mathrm{n}=43$, mean \pm standard error. (b) Skeletal $(\mathrm{mg}) /$ chlorophyll a $(\mu \mathrm{g})$ ratios, $\mathrm{n}=43$, mean \pm standard error

tion rates at each recovery time, in order to test for total recovery (i.e. stable growth rates) of the microcolonies. The SAS (1993) procedure NLIN was used to fit non-linear regression curves relating log growth rate to recovery time when growth differed significantly ( $p<0.05$ ) between recovery times. The nonlinear curves consisted of 2 segments: a quadratic curve of log growth rate before a transition point, followed by a constant growth rate indicating stable growth. For each segmented curve, 5 parameters were estimated: 3 for the quadratic, 1 for the transition point and 1 for the final stable growth rate. $\mathrm{R}^{2}$ values were calculated to indicate the percentage of variation between recovery times explained by the fitted curve.

\section{RESULTS}

\section{Microcolony composition}

Wet weight, protein, chlorophyll and skeletal mass were measured and analysed as proportions to document the variation of composition of the microcolonies. We observed wide variations of protein (mg)/wet weight $(\mathrm{g})$ ratios $(87.80 \pm 0.63 \mathrm{SE}, \mathrm{n}=16)$ The skeletal/protein and skeletal/chlorophyll mass ratios also showed variation between microcolonies and between regions. Chlorophyll was clearly concentrated in the polyps while protein was more evenly distributed in the microcolony (Fig. 2).
Table 1. Litophyton arboreum. Mean logarithm of growth rate at each recovery time for each microcolony region. Means not followed by the same letter are significantly different $(\mathrm{p}<$ $0.05)$. The $5 \%$ least significant difference (LSD) value is given for each region

\begin{tabular}{|lccc|}
\hline $\begin{array}{l}\text { Recovery } \\
\text { time (d) }\end{array}$ & \multicolumn{3}{c|}{$\begin{array}{c}\text { Microcolony region } \\
\text { Polyp }\end{array}$} \\
\hline 1 & Stem & $3.72 \mathrm{a}$ & $3.72 \mathrm{a}$ \\
3 & $3.73 \mathrm{a}$ & $3.69 \mathrm{a}$ & $3.70 \mathrm{a}$ \\
7 & $3.81 \mathrm{a}$ & $3.96 \mathrm{~b}$ & $4.04 \mathrm{~b}$ \\
14 & $4.31 \mathrm{~b}$ & $4.01 \mathrm{~b}$ & $4.19 \mathrm{~b}, \mathrm{C}$ \\
21 & $4.60 \mathrm{~b}$ & $3.97 \mathrm{~b}$ & $4.16 \mathrm{~b}, \mathrm{c}$ \\
28 & $4.49 \mathrm{~b}, \mathrm{c}$ & $3.97 \mathrm{~b}$ & $4.16 \mathrm{~b}, \mathrm{C}$ \\
35 & $4.52 \mathrm{~b}, \mathrm{c}$ & $3.95 \mathrm{~b}$ & $4.23 \mathrm{c}, \mathrm{d}$ \\
42 & $4.47 \mathrm{~b}, \mathrm{c}$ & $4.09 \mathrm{~b}$ & $4.21 \mathrm{c}, \mathrm{d}$ \\
49 & $4.55 \mathrm{~b}, \mathrm{c}$ & $4.11 \mathrm{~b}$ & $4.37 \mathrm{~d}$ \\
LSD & $4.76 \mathrm{c}$ & 0.15 & 0.17 \\
& 0.31 & & \\
\hline
\end{tabular}

\section{Cell growth}

At all times, stems grew at a faster rate than polyps, measured as incorporation of thymidine, i.e. synthesis of DNA (Fig. 3), and had greater ${ }^{3} \mathrm{H}-\mathrm{T}$ incorporation variability. Two phases of growth rates were observed in both colony regions, immediately after dissection (Days 1 and 3) the growth rates were at their minimum value and increased noticeably by Day 7 , reaching a plateau value after approximately $15 \mathrm{~d}$. The cut colony fragments required a period of recovery before they showed a stable state of growth rate.

LSD analysis indicated that growth rates at Days 1 and 3 were significantly different from the rest in both colony regions; the corresponding groupings are shown in

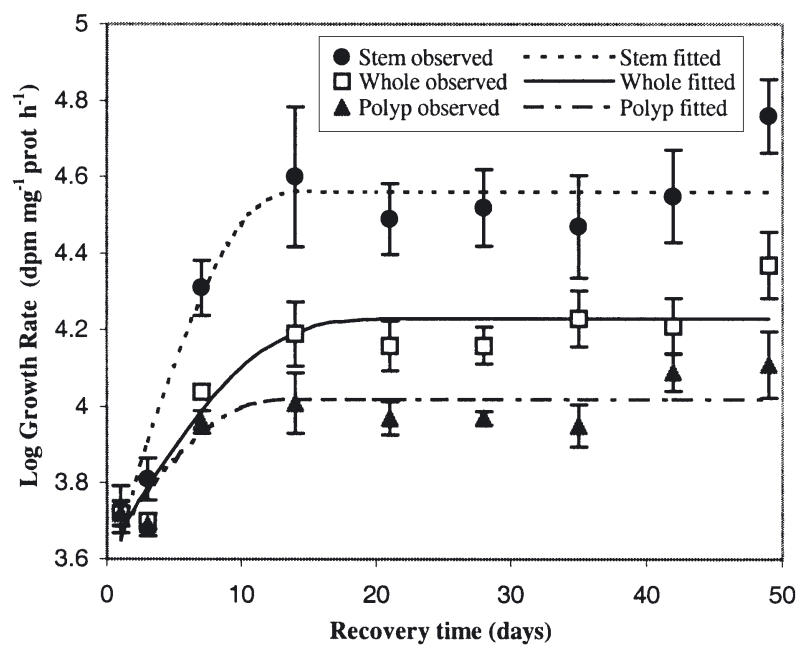

Fig. 3. Litophyton arboreum. Effect of recovery from colony dissection on cell growth rates. The mean log growth rate ( \pm standard error) at each recovery time is given for each region along with the curve fitted through the points $(n=6)$ See the text for details concerning the fitted curve 
Table 1. A quadratic curve was fitted to the logarithm of growth rate versus recovery time for each region (Fig. 3). The coefficients of the quadratic curve, the transition point and the stable growth rate are indicated in Table 2.

\section{Calcification rates}

In contrast to the cell growth rate responses, the fully recovered microcolonies did not show a clear difference in calcification potential between regions (Fig. 4). The effect of recovery time on calcification rates was significant in stems $(\mathrm{p}=0.013)$ but not in polyps $(\mathrm{p}=$ 0.054) (Table 3).

\section{DISCUSSION}

\section{Method validity}

Since the rate of DNA synthesis correlates with cell division, it has been used to estimate growth rates in various organisms. Incorporation of thymidine into DNA, however, needs to be carefully interpreted. Robarts \& Zohary (1993) present a thorough review of the problems involved in this method when applied to microorganisms. The method assumes that exogenous ${ }^{3} \mathrm{H}-\mathrm{T}$ is incorporated into DNA (salvage pathway). Two problems arise: (1) lack of the necessary enzymes to phosphorylate ${ }^{3} \mathrm{H}-\mathrm{T}$, resulting in synthesis of DNA by an alternative mechanism (de novo pathway) not being detected by radiotracers; and (2) fast metabolism of ${ }^{3} \mathrm{H}-\mathrm{T}$, resulting in non-specific labelling (i.e. ${ }^{3} \mathrm{H}$-methyl

Table 2. Litophyton arboreum. Estimated parameters for the fitted curve of the logarithm of growth rate versus recovery time which is shown in Fig. 3 for each region. The quadratic curve is given by the equation $\mathrm{a}(\text { day })^{2}+\mathrm{b}($ day $)+\mathrm{c}$ where day is recovery time. The equation models log (growth rate) before the time of transition, after which the logarithm of growth rate is stable. The $R^{2}$ value is the percentage of the treatment

sum of squares, which is explained by the fitted curve

\begin{tabular}{|lccc|}
\hline \multicolumn{4}{c|}{ Microcolony region } \\
& Stem & Polyp & Whole \\
\hline Quadratic curve & & & \\
a & -0.005270 & -0.002612 & -0.001910 \\
$\mathrm{~b}$ & 0.1492 & 0.0659 & 0.0689 \\
$\mathrm{C}$ & 3.509 & 3.602 & 3.604 \\
Transition recovery & 14.2 & 12.6 & 18.0 \\
time (d) & & & \\
Stable log growth rate & 4.56 & 4.02 & 4.22 \\
(dpm prot mg & \\
$\mathrm{R}^{-1}$ ) & & & \\
& $93 \%$ & $81 \%$ & $90 \%$ \\
\hline
\end{tabular}

Table 3. Litophyton arboreum. Mean logarithm of calcification rate at each recovery time for stem and polyp sections. Means not followed by the same letter are significantly different $(p<0.05)$. The $5 \%$ least significant difference (LSD) value is given for each region, unless the $F$ statistic was not significant (ns $=\mathrm{p}>0.05)$

\begin{tabular}{|lcc|}
\hline $\begin{array}{l}\text { Recovery } \\
\text { time (d) }\end{array}$ & \multicolumn{2}{c|}{$\begin{array}{c}\text { Microcolony region } \\
\text { Stem }\end{array}$} \\
\hline 7 & $1.12 \mathrm{a}$ & Polyp \\
15 & $1.61 \mathrm{a}, \mathrm{b}$ & $1.76 \mathrm{a}$ \\
51 & $2.06 \mathrm{~b}$ & $1.46 \mathrm{a}$ \\
81 & $1.61 \mathrm{a}, \mathrm{b}$ & $1.98 \mathrm{a}$ \\
LSD & 0.50 & $1.86 \mathrm{a}$ \\
& & ns \\
\hline
\end{tabular}

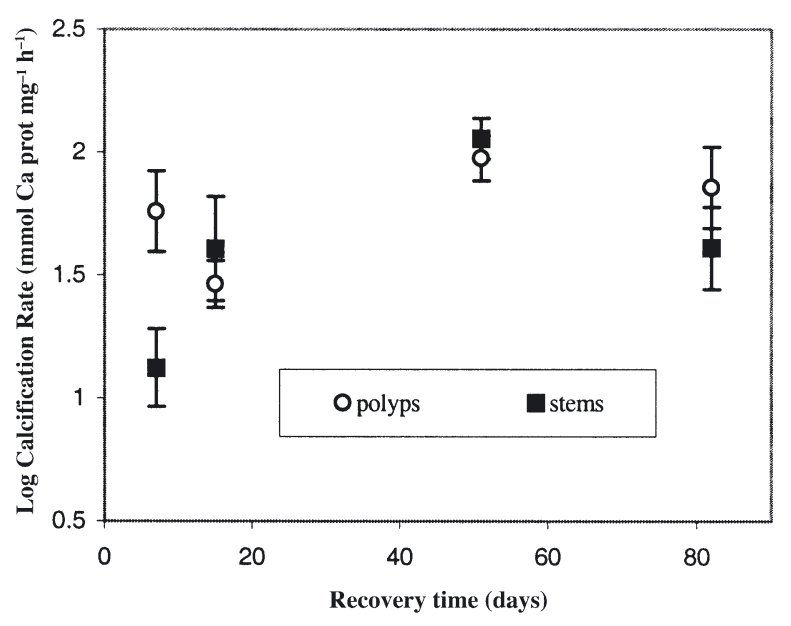

Fig. 4. Litophyton arboreum. Effect of recovery from colony dissection on calcification rates. The mean log calcification rate $( \pm$ standard error) at each recovery time is given for stems and polyps sections $(n=6)$

attached to other macromolecules). ${ }^{3} \mathrm{H}-\mathrm{T}$ has been successfully applied to measure cell renewal in the corals Acropora sp., Pavona sp. and Pocillopora sp. (Cheney 1973) and to follow cell migration by autoradiography in the sea anemone Halioplanella luciae (Minasian 1979). This indicates that cnidarians have the necessary enzymes to incorporate the labelled nucleoside into their DNA. By keeping within the time of ${ }^{3} \mathrm{H}-\mathrm{T}$ exposure used in previous cnidarian experiments, our method avoids the confounding effect of non-specific labelling. It is important to note that the incorporation of ${ }^{3} \mathrm{H}-\mathrm{T}$ by free-living photosynthetic eukaryotes has been reported to be not detected, not significant, or detected only after $6 \mathrm{~h}$ of exposure (Robarts \& Zohary 1993). Cheney (1973) reported no uptake of ${ }^{3} \mathrm{H}-\mathrm{T}$ by zooxanthellae of scleractinian corals during exposures of up to $1 \mathrm{~h}$. We assume our method detects only the DNA synthesis of soft coral cells and does not include zooxanthellae. 
The samples incubated in ${ }^{45} \mathrm{Ca}$ were washed and their efflux medium was monitored for $3 \mathrm{~h}$ to avoid excess marker in their gastric cavities (Allemand \& Grillo 1992, Tambutté et al. 1995a). Only the washed skeletal component was considered in the measurement of calcification rates. Although it is true that incubation time could have an effect on the hourly rates of cell growth and calcification, keeping both series of experiments to $2 \mathrm{~h}$ incubation allows direct comparisons of responses. A brief incubation time also reduces the likelihood of important shifts in protein content during the experiment (Gates \& Edmunds 1999).

Normalising growth and calcification rates per protein content has been an accepted practice in the study of scleractinian and gorgonian corals (Tambutté et al. 1995a,b, 1996, Allemand \& Bénazet-Tambutté 1996). However, it is not unusual to find a large amount of extracellular protein as part of the coenenchyme in soft corals, particularly towards the basal parts of the colony as illustrated by Chevalier et al. (1984). Our method does not differentiate between extracellular and intracellular protein. For this reason, it is more likely that the cell growth and calcification rates are underestimated in the stem than in the polyp region, in the present investigation.

\section{Trend of recovery}

After dissection, the microcolonies need to form a scar and reattach onto a firm substrate. The most active cells were recorded in the stem region, as expected. In the first week of recovery, the growth rate of soft coral microcolonies increased slightly. These responses agree with the findings presented in the review by Gates \& Edmonds (1999), i.e. growing slows down in corals if there is a need to divert metabolism towards adaptation to a changing environment, caused in these experiments by tissue injury.

Studies of ${ }^{3} \mathrm{H}-\mathrm{T}$ incorporation in Pocillopora damicornis, carried out by Cheney (1973), indicated a higher growth rate $48 \mathrm{~h}$ after injury than in the uninjured colony. However, careful examination of the method shows that the colony reported as uninjured was actually a freshly sectioned coral branch; the correct interpretation should therefore state that immediately after injury, the coral shows a reduced growth rate. Such a response would be consistent with the trend of cell growth rate that we observed in Litophyton arboreum, and seems to contradict the data found by Marchioretti (1990) with Stylophora pistillata nubbins. Marchioretti (1990) found maximum coral growth rate within the first $7 \mathrm{~d}$ after cutting and transplanting the nubbins, and lower, stable growth rates between 27 and 46 d. However, he measured growth as buoyant weight increment, which corresponds mainly to skeletal growth, as stated by Davies (1989), not to cell growth. Finally, field observations of transplanted branches of the soft coral Dendronephthya sp. (Fabricius et al. 1995) described the gradual growth of rhizoids followed $10 \mathrm{~d}$ later by the formation of new polyps and growth of stems. Cheney (1973), Marchioretti (1990) and Fabricius et al. (1995) deal with short term $(2,46$ and $10 \mathrm{~d}$ respectively) effects of colony sectioning on growth rate, measuring growth by DNA synthesis, skeleton formation or change of colony shape. The various methods employed show different aspects of growth; nonetheless, all suggest that in growth experiments involving relocated or fragmented corals, the recovery time must be taken into account. We advise caution in the interpretation of results obtained within the first 4 to $6 \mathrm{wk}$ of recovery from tissue injury. Our experiments indicate that, in both colony regions, actual cell growth rate increases after $3 \mathrm{~d}$ of microcolony preparation. The calcification rates do not show a clear pattern of change through recovery time. The repair mechanisms that operate in the microcolonies in the first few days are not known, but clearly involve more than new tissue synthesis.

We attribute the observed range of growth and calcification rates to several possible sources of variation: (1) the combined effect of intercolonial variability, (2) the growth potential of the branches according to their position in the colony, and (3) the possibility that cell regeneration of the microcolonies was affected by our preventing their attachment onto the substrate. Such interference would result in a 'noisy' plateau phase of growth rate and would affect the stem region in particular. However, this difference is not significant according to LSD tests on whole microcolony, polyps or stem regions (Table 1).

\section{Polarity of functions in the colony}

The present study points out important physiological differences between stems and polyps in Litophyton arboreum. Both fragments of the soft coral colony responded with increasing growth and calcification rates through time. Fig. 3 illustrates the wide difference between stems and polyps regarding cell growth, while Fig. 4 shows no significant difference between calcification rates of colony regions. In comparison with the polyp region, stems of $L$. arboreum are poor in zooxanthellae and protein content but rich in calcium carbonate (Fig. 2), and they also seem to have a high proportion of non-cellular mesogleal components. Our attempts to produce microcolonies from small fractions of discs and stems of Sarcophyton sp. (a soft coral with 
a mushroom shape) resulted in decaying discs but successful regeneration of polyps on both sides of stem sections. These observations suggest that colony regeneration is greatly affected by stem properties.

Most manipulative studies of soft corals use whole body measurements or do not specify any particular region as the material under analysis. Our study highlights the need to consider the structural and functional complexity of the soft coral body in future studies. The possibility of differential growth and calcification responses observed in Litophyton arboreum agrees with reports on differential elemental composition (Tentori et al. 1997), differential secondary metabolite production (Van Alstyne et al. 1994) and differential trophic activity (Widdig \& Schlichter 2001) of other alcyonacean species. The soft coral colony is not a homogeneous mass.

\section{CONCLUSION}

The mechanisms of cell growth and calcification have co-evolved in tropical corals over millions of years. The tight structural link between their skeleton and coral tissue confounds the physiological controls that occur within the coral colony. In the case of scleractinian corals, cell and skeletal growth have been regarded as directly linked mechanisms (Muscatine et al. 1985). The relatively high calcification rates of the colony tips observed in branching coral and gorgonian colonies has been attributed to a corresponding high cellular activity (Gladfelter et al. 1989, Kingsley \& Watabe 1989). However, deposition of calcium carbonate can result in extension of the coral skeleton or in increase of the skeletal density (Barnes \& Crossland 1980, Dodge \& Brass 1984, Carricart-Gavinet \& Merino 2001). Having detected separate processes of calcification in branching corals, Barnes \& Crossland (1980) also hinted that tissue growth might well be controlled by different factors from those controlling skeletal growth. The separate nature of cell growth and skeletal growth is shown in the present study. We conclude that soft corals can be used as a physiological model to separate and understand mechanisms that are intricately related, occurring simultaneously and at the same sites in scleractinian corals.

Acknowledgements. We thank the research team of the Centre Scientifique de Monaco (CSM) for their valuable discussions and consistent help with analytical aspects of this study, especially to P. Furla and M. Marchioretti. The Oceanographic Museum of Monaco kindly provided the soft coral material on which this study was based. Our work was supported by research funds of the CSM. E.T. was supported by a sabbatical grant from CQU and by the hospitality of the CSM.

\section{LITERATURE CITED}

Alino P, Sammarco P, Coll JC (1992) Competitive strategies in soft corals (Coelenterata, Octocorallia). Environmentally induced reversals in competitive superiority. Mar Ecol Prog Ser 81:129-145

Allemand D, Bénazet-Tambutté S (1996) Dynamics of calcification in the Mediterranean red coral, Corallium rubrum. J Exp Zool 276:270-278

Allemand D, Grillo MC (1992) Biocalcification mechanisms in gorgonians: $45 \mathrm{Ca}$ uptake and deposition by the Mediterranean red coral Corallium rubrum. J Exp Zool 262: 237-246

Al-Moghrabi S, Allemand D, Jaubert J (1993) Valine uptake by the scleractinian coral Galaxea fascicularis: characterisation and effect of light and nutritional status. J Comp Physiol B 163:355-362

Al-Moghrabi S, Allemand D, Jaubert J (1995) Fatty acids of the scleractinian coral Galaxea fasciularis and its symbiont: effect of light and feeding. J Comp Physiol B 165: 183-192

Barnes DJ, Crossland C (1980) Diurnal and seasonal variations in the growth of a staghorn coral measured by timelapse photography. Limnol Oceanogr 25:1113-1117

Benayahu Y, Weil D, Kleinman M (1990) Radiation of broadcasting and brooding patterns in coral reef alcyonaceans. In: Yamashita $\mathrm{O}$ (ed) Advances in invertebrate reproduction 5. Elsevier, Amsterdam, p 323-328

Benayahu Y, Weil D, Malik Z (1992) Entry of algal symbionts into oocytes of the coral Litophyton arboreum. Tissue Cell 24:473-482

Berner T, Achituv Y, Dubinsky Z, Benayahu Y (1987) Pattern of distribution and adaptation to different irradiance levels of zooxanthellae in the soft coral Litophyton arboreum (Octocorallia, Alcyonacea). Symbiosis 3:23-40

Bradford MM (1976) A rapid and sensitive method for the quantitation of microgram quantities of protein utilizing the principle of protein-dye binding. Anal Biochem 72: $248-254$

Carricart-Gavinet J, Merino M (2001) Growth responses of the reef-building coral Montastrea annularis along a gradient of continental influence in the southern Gulf of Mexico. Bull Mar Sci 68:133-146

Cheney DP (1973) Cell proliferation as an index of growth in corals: incorporation of 3H-Thymidine. Recent trends in research in coelenterate biology. 2nd Int Symp Cnidaria, Brisbane

Chevalier JP, Doumenc D, Herberts C, Lafuste J, SemenoffTian-Chansky P, Tiffon Y, Tixier-Durivault A, Van-Praet M (1984) Cnidaires Anthozoaires (Anthozoa Ehrenberg, 1834). In: Grassé PP (ed) Traité de zoologie. Anatomie, systématique, biologie. Masson, Paris, p 1-185

Coll JC (1992) The chemistry and chemical ecology of octocorals (Coelenterata, Anthozoa, Octocorallia). Chem Rev 92:613-631

Davies S (1989) Short-term growth measurements of corals using an accurate buoyant weighing technique. Mar Biol 101:389-395

Dodge R, Brass G (1984) Skeletal extension, density and calcification of the reef coral Montastrea annularis: St Croix US Virgin Islands. Bull Mar Sci 34:288-307

Done TJ (1992) Phase shift in coral reef communities and their ecological significance. Hydrobiologia 247:121-132

Fabricius KE, Genin A, Benayahu Y (1995) Flow-dependent herbivory and growth in zooxanthellae-free soft corals. Limnol Oceanogr 40:1290-1301

Furla P, Galgani I, Durand I, Allemand D (2000) Sources and 
mechanisms of inorganic carbon transport for coral calcification and photosynthesis. J Exp Biol 203(22):3445-3457 Gates R, Edmunds P (1999) The physiology mechanisms of acclimatization in tropical reef corals. Am Zool 39:30-43

Gattuso JP, Yellowlees D, Lesser M (1993) Depth and lightdependent variation of carbon partitioning and utilization in the zooxanthellate scleractinian coral Stylophora pistillata. Mar Ecol Prog Ser 92:267-276

Gattuso JP, Allemand D, Frankignoulle M (1999) Photosynthesis and calcification at cellular, organismal and community levels in coral reefs: A review on interactions and control by carbonate chemistry. Am Zool 39:160-183

Gladfelter E (1983) Skeletal development in Acropora cervicornis. II. Diel patterns of calcium carbonate accretion. Coral Reefs 2:91-100

Gladfelter E, Michel G, Sanfelici A (1989) Metabolic gradients along a branch of the reef coral Acropora palmata. Bull Mar Sci 44:1166-1173

Goiran C, Al-Moghrabi S, Allemand D, Jaubert J (1996) Inorganic carbon uptake for photosynthesis by the symbiotic coral/dinoflagellate association. I. Photosynthetic performances of symbionts and dependence on sea water bicarbonate. J Exp Mar Biol Ecol 192:207-225

Goreau TF (1959) The physiology of skeleton formation in corals. I. A method for measuring the rate of calcium deposition by corals under different conditions. Biol Bull 116: 59-75

Isa Y, Yamazato K (1981) The ultrastructure of calicoblast and related tissues in Acropora hebes (Dana). Proc 4th Int Coral Reef Symp, Manila, 1981. 2:99-105

Johnston I (1980) The ultrastructure of skeletogenesis in hermatypic corals. Int Rev Cytol 67:171-214

Kingsley R, Watabe N (1989) The dynamics of spicule calcification in whole colonies of the gorgonian Leptogorgia virgulata (Lamarck) (Coelenterata: Gorgonacea). J Exp Biol Ecol 133:57-65

Maida M, Sammarco PW, Coll JC (2001) Effects of soft corals on scleractinian coral recruitment. II Allelopathy, spat survivorship and reef community structure. PSZN I: Mar Ecol 22:397-414

Marchioretti M (1990) Influence de la lumière sur la calcification de deux scleractiniares azooxanthelles: Stylophora pistillata (Esper, 1797), Hydnophora exesa (Pallas, 1766). MSc dissertation, Faculté des Sciences et Techniques de Saint Jerome, Marseille

Marshall AT (1996) Calcification in hermatypic and ahermatypic corals. Science 271:637-639

Marshall A, Wright O (1993) Confocal laser scanning light microscopy of the extra-thecal epithelia of undecalcified scleractinian corals. Cell Tissue Res 272:533-543

Minasian L (1979) The distribution of proliferating cells in an anthozoan polyp, Haliplanella lucia (Actinaria: Acontiaria), as indicated by $3 \mathrm{H}$-thymidine incorporation. In: Tardent R (ed) Developmental and cellular biology of coelenterates. Elsevier, Interlaken, p 415-420

Editorial responsibility: Charles Birkeland (Contributing Editor), Honolulu, Hawaii, USA
Muscatine L, McCloskey L, Loya Y (1985) A comparison of the growth rates of zooxanthellae and animal tissue in the Red Sea coral Stylophora pistillata. Proc 5th Int Coral Reef Congr, Tahiti, 1985. 6:119-123

Ninio R, Meekan MG (2002) Spatial patterns in benthic communities and the dynamics of a mosaic ecosystem on the Great Barrier Reef, Australia. Coral Reefs 21:95-103

Reichelt RE, Loya Y, Bradbury RH (1986) Patterns in the use of space by benthic communities on two coral reefs of the Great Barrier Reef. Coral Reefs 5:73-79

Rinkevich B, Loya Y (1984) Does light enhance calcification in hermatypic corals? Mar Biol 80:1-6

Robarts R, Zohary T (1993) Fact or fiction-bacterial growth rates and production as determined by [methyl-3H]thymidine? In: Gwynfryn Jones J (ed) Advances in microbial ecology. Plenum Press, New York, p 371-425

Romaine S, Tambutté É, Allemand D, Gattusso JP (1997) Photosynthesis, respiration and calcification of a zooxanthellate scleractinian coral under exposed and submerged conditions. Mar Biol 129:175-182

SAS (1993) SAS/STAT user's guide. SAS Institute, Cary, NC

Tambutté É, Allemand D, Bourge I, Gattusso JP, Jaubert J (1995a) An improved 45Ca protocol for investigating physiological mechanisms in coral calcification. Mar Biol 122:453-459

Tambutté É, Allemand D, Jaubert J (1995b) The Stylophora pistillata microcolony: a model for studying calcium transport process during coral biomineralization. Bull Inst Océanogr 14:79-87

Tambutté É, Allemand D, Mueller E, Jaubert J (1996) A compartmental approach to the mechanism of calcification in hermatypic corals. J Exp Biol 199:1029-1041

Tentori E (1999) Effects of Cyclone Joy 1991 flood on the fringing reefs of Keppel Bay (Mackay-Capricorn Section of the Great Barrier Reef): Recovery phase. Central Queensland University, Rockhampton

Tentori E, Coll J, Fleury B (1997) ENCORE: Effects of elevated nutrients on the C:N:P ratios of Sarcophyton sp (Alcyonacea). Proc8th Int Coral Reef Symp, Panama, 1996. 1: 885-890

Tursch R, Tursch A (1982) The soft coral community on a sheltered reef quadrat at Laing Island (Papua New Guinea). Mar Biol 68:321-323

Vago R, Dubinsky Z, Genin A, Ben-Zion M, Kizner Z (1997) Growth rates of three symbiotic corals in the Red Sea. Limnol Oceanogr 42:1814-1819

Van Alstyne K, Wylie C, Paul V (1994) Antipredator defenses in tropical Pacific soft corals (Coelenterata: Alcyonacea). II. The relative importance of chemical and structural defenses in three species of Sinclair. J Exp Mar Biol Ecol 178:17-34

Widdig A, Schlichter D (2001) Phytoplankton: a significant trophic source for soft corals? Helgol Mar Res 55:198-211

Williams G (1992) The Alcyonacea of Southern Africa. Stoloniferous octocorals and soft corals (Coelenterata, Anthozoa). Ann S Afr Mus 100:248-359

Submitted: May 17, 2003; Accepted: March 30, 2004

Proofs received from author(s): July 7, 2004 